\title{
Eğitim Kurumu Çalışanlarının Presenteeism (İşte Var Olamama) Algılarının Performanslarına Olan Etkisi ve Sosyo-Demografik Özellikler Açısından İncelenmesi
}

DOI: 10.26466/opus.595134

$*$

\author{
Hüseyin Çiçeklioğlu ${ }^{*}$ - Mustafa Taşlıyan** \\ * Öğr.Gör.Dr., Mersin Üniversitesi, Turizm Fakültesi, Yenişehir / Mersin / Türkiye \\ E-Posta: huseyinciceklioglu@gmail.com ORCID: 0000-0003-3922-6755 \\ ** Prof. Dr., Kahramanmaraş Sütçü İmam Üni., İ.I.B.F., Oniki Şubat / Kahramanmaraş/ Türkiye \\ E-Posta: mustafatasliyan@hotmail.com ORCID: 0000-0003-1141-9846
}

Öz

Presenteeism (işte var olamama) çalışanların hasta olmalarına, ruhsal ve fiziksel açıdan problem yaşamalarına rağmen iş yerinde olmaları ve düşük verimlilik seviyesinde çalışmaları şeklinde tanımlanmaktadır. Presenteeism kavramı, işyerinde performans, verimlilik ve sağhlğa ilişkin henüz ortaya çıkan bir olgu olmasına rağmen örgütlerin dikkatle ele alması gerekli konuların başında gelmektedir. Bu araştırmanın amacl; eğitim kurumlarında çalı̧̧an öğretmenlerin presenteeism algilarının performanslarına olan etkilerini analiz etmek ve bu eylemlerin bazı değişkenlere göre farklılık gösterip göstermediğini ortaya koymaktır. Bununla birlikte bu araştırma değ ģskenleri arasındaki ilişkilerin düzeyinin ve yönünün de tespit edilmesi amaçlanmıştır. Bu amaçlar doğrultusunda, Akdeniz bölgesinde yer alan Mersin ve Kahramanmaraş illerinde faaliyet gösteren eğitim kurumlarında görevli 829 öğretmene anket uygulanmıştır. Anket sonucunda elde edilen verilere SPSS paket programı kullanılarak korelasyon, regresyon, Kruskall-Wallis ve Mann-Whitney $U$ analizi testleri uygulanmıştır. Araştırma sonuçlarına göre; presenteeism ile işgören performansı arasında negatif yönde anlamlı ilişkinin varlı̆̆l, presenteeismin "işi tamamlama" boyutunun işgören performansın negatif yönde etkilediği ve "dikkat dağınıklığından kaçınma" boyutunun ise işgören performansı üzerinde anlamlı bir etkisinin olmadı̆̆ ve sosyo-demografik özelliklerinin araştırma değişkenleri üzerinde anlamlı bir farklılığa sebebiyet vermediği tespit edilmiştir

Anahtar Kelimeler: Presenteeism, İşgören Performansı, Demografik Özellikler 


\title{
The Effects of Presenteeism Perceptions of Educational Institution Employees on Their Performance and It's Analysis With Regardds to the Socio-Demographic Characteristics
}

$*$

\begin{abstract}
Presenteeism (not being on the job actively) is defined as being at work not fully functioning because of reduced performance although they are sick and having mental or physical problems. Although the term of Presenteeism is a phenomenon just introduced regarding to the performance, productivity, and health at work, it is one of the main issues, which should be discussed carefully. The aim of this study is to analyze the effect of presenteeism perception of teachers working in educational intuitions on their performance and to reveal whether these actions differ according to some variables. In addition to this, it is aimed to establish the level and the direction of the relations between the variants of the study. In accordance with this purpose, a questionnaire has been carried out on 829 teachers working in the educational intuitions in Mersin and Kahramanmaraş located in Mediterranean Region of Turkey. Correlation, regression, Kruskall-Wallis, and Man-Whitney U analysis tests made on the data acquired from the questionnaire using SPSS programme. According to the result of the study, it has been determined that; there is a meaningful negative relationship between presenteeism and employee performance, "completing work" dimension of presenteeism effects employee performance negatively, there is no meaningful effect of "avoiding distraction" dimension on employee performance, and socio-demographic characteristics do not cause a meaningful difference on the variables of the study.
\end{abstract}

Keywords: Presenteeism, Employee Performance,Demographic Characteristics 


\section{Giriş}

İşletmeler arasındaki rekabetin şiddetinin artmasına; küreselleşmenin etkisini net bir şekilde hissettirmesi, hem uluslararası hem de ulusal bazda ekonominin işletmeler üzerindeki etkisi ve tüketici davranışlarında meydana gelen ani değişimler sebebiyet vermektedir. İnsan kaynakları, günümüz endüstri toplumlarında finansal yapı, teknolojik imkan, makine-teçhizat, fırsat ve yenilikler açısından birbirine son derece yakın olan işletmelerin sürdürülebilir rekabetçi avantaj sağlama adına en önemli olgudur. İnsan kaynakları artık işletmeler adına ek bir maliyet unsuru olarak görülmemekte aksine üzerinde önemle durulması ve geliştirilmesi gerekli stratejik bir unsur olarak görülmektedir. Örgütsel performans, etkinlik ve verimliliğin artırılması ve arzulanan başarıların gerçekleştirilebilmesinin sadece fiziksel ve ruhsal açıdan sağlıklı bireylerle sağlanabilecek olması insan kaynaklarının stratejik bir unsur olarak değerlendirilmesindeki en önemli husustur.

Günümüzde yoğun bir şekilde artış gösteren rekabet olgusuyla birlikte performans konusu da işletmeler adına oldukça stratejik bir önem kazanmıştır. $\mathrm{Bu}$ stratejik önemin sebebi ise, işletmelerin arzuladığ sürdürülebilir rekabetçi avantajı sağlamanın yolunun hem bireysel hem de işletme performansının birlikte arttırılması gerekliliğidir. Bu amaç doğrultusunda, ilk olarak işgören performansı artırılmalıdır. Çünkü işgören performansının artması doğrudan işletme performansının da artmasına sebebiyet verecektir. İşte bu noktada işgören performansının bireysel olarak arttırılmasının önündeki en büyük engellerden birisi olan presenteeism karşımıza çıkmaktadır.

Presenteeism olgusu çalışanların hastalanmalarına, ruhsal ve fiziksel açıdan problemli olmalarına rağmen işyerlerinde olmaları ve düşük verimlilik düzeyinde çalışmaları olarak tanımlanmakla birlikte işyerinde performans, verimlilik ve sağlıkla ilgili henüz ortaya çıkan bir kavram olarak işletmelerin üzerinde dikkatle durması gerekli problemlerin başında gelmektedir.

Öğretmenlerde çoğu çalışan gibi bazı zamanlarda çeşitli sebepler dolayısıyla hasta olmalarına rağmen işe gitmektedirler. Öğrencilerin derslerinin aksayabileceği, okuldaki işlerin birikebileceği, veliler, diğer öğretmenler ve yönetim tarafından yanlış değerlendirilecekleri düşüncesi 
veya ders ücretlerinin kesilmesi gibi endişeleri dolayısıyla hasta olmalarına rağmen öğretmenler iş yerlerine gitmektedirler.

Araştırma amaçları doğrultusunda, ilk olarak presenteeism ve işgören performansı kavramları açılanacak, akabinde ise araştırma yöntemi ve alan araştırmasıyla ilgili bulgular ortaya konulacak ve elde edilen sonuçlar yorumlanıp, öneriler getirilecektir.

\section{Presenteeism (İşte Var Olamama)}

Oxford English Dictionary Online'a göre presenteeism (işte var olamama) kavramı ilk olarak 1982 yılında Amerikalı mizahçı ve yazar Mark Twain tarafından çıkartılan "The American Claimant" adlı kitapta kendisine yer bulmuştur. Presenteeism kavramı ilk kullanımlarının çoğunda ya tam katılım olarak ya da devamsızlık olarak net ayrımlarla ele alınmıştır. Fakat Söz konusu kavramlar arasındaki farklar 1980'li yıllardan sonra daha net bir şekilde ortaya çıkmaya başlamıştır (Johns, 2010:520). Presenteeism olgusu, 1990'lı yılların ortalarından itibaren yönetim alan yazınındaki mesleki üretkenlik dergilerine girdikten hemen sonra, sağllğa yönelik alan yazınlarında da yer almıştır. Presenteeism olgusu özellikle, örgütsel açıdan üretkenliğin azalmasına neden olduğu için örgütler adına oldukça ciddi bir önem kazanmış ve yöneticiler tarafından örgütsel etkinliğe yönelik net bir şekilde anlaşılması ve kontrol altında tutulması gereken bir kavram özelliği kazanmıştır (Kim vd., 2016, s.32).

Son dönemlerde iş yaşamında devamsızlık olarak tanımlanan "hastayım bugün işe gitmeyeceğim" düşüncesinin yerine presenteeism olarak tanımlanan "hastayım fakat işteyim" düşüncesinin yer alması konusundaki tartışmalar güç geçtikçe şiddetlenmektedir. 2010 yılında Günbeyi ve Gündoğdu tarafından gerçekleştirilen çalışmalarda presenteeism olgusu "işkoliklik" olarak ele alınmıştır (Günbeyi ve Gündoğdu, 2010, s.56).

Presenteeism kavramının kelime anlamı tam olarak işgörenin fiziken var olması durumunu ifade etmektedir. Hem fonetik hem de kavramsal açıdan birbirlerine yakınlık göstermekte olan "absenteeism" (devamsızlık) olgusundan yola çıkmak suretiyle presenteeism tanımlanabilir. "Absenteeism" kavramı "absence" kelimesinden türetilmiş olup devamsızlık, yokluk ve bulunamama anlamlarına gelmektedir. Absenteeism 
kavramı sözcük anlamı açısından ele alındığında ise fiziksel açıdan mevcut bulunamamaya işaret etmektedir. Presenteeism olgusunu net ve tam bir şekilde ifade edebilmek adına Türkçe kavram arayışları devam etmekte ve genel olarak "işte var olamama" kavramının kullanıldığ görülmektedir. Bunun temel nedeni ise; işte var olamama kavramı, işgörenlerin işyerinde fiziksel açıdan hazır olmalarına rağmen, fiilen yer alamama sorununu meydana getirmesidir.

1996 yılında Amerikalı örgütsel psikolog Cary Cooper tarafından presenteeism kavramı ortaya atılmıştır. Cooper tarafından presenteeism; "işgörenlerin karşı konulamayacak düzeyde uzun süreler boyunca çalışması ya da çalışıyormuş gibi görünmesi" şeklinde tanımlanmıştır (Saarvala, 2006, s.3). Presenteeism, Tükeltürk ve arkadaşları (2014, s.282) tarafından; "işgörenlerin belirli bir sağlık problemi sebebiyle tam bir verimlilik seviyesinde çalışamamalarına rağmen işyerinde var olmaları" şeklinde ele alınmıştır.

Presenteeism olgusu, alan yazınına girdiği ilk andan itibaren negatif yönlü bir davranış olarak ele alınmış olsa da uzun vadede tam bir örgütsel vatandaşlık davranışı olarak kabul görmüştür. Presenteeism, işgörenler adına içerisinde risk barındıran bir davranış şeklidir. Çünkü küçük düzeylerdeki problem ve hastalıkları görmezden gelerek sürekli rahatsızlık izinlerini ertelemek ilerde daha ciddi rahatsızlıkların ortaya çıkmasına sebep olabilecektir. Presenteeism olgusunun örgüte zararı, işgörenlerin devamsızlık yapmalarından çok daha yüksek düzeylerdedir. İşgörenlerde görülen presenteeism davranışları, bireylerin küçük düzeyli rahatsızlıklarının birleşmesi neticesinde çok daha ciddi problemlere dönüşerek örgütün karşısına çıkabilmektedir. İlgili alan yazınında konuya yönelik gerçekleştirilen çalışmalar incelendiğinde baş ağrısı ve alerji gibi içerik bakımından genel nitelikli kabul edilen hastalıklar nedeniyle ortaya çıkan üretim kayıplarının, örgüt içerisinde çalışan bütün işgörenlere yapılacak olan toplam sağlık harcamalarının \%70'inden daha yüksek olduğu görülmektedir.

İşgörenlerin işyerlerinde çalışma esnasında tam kapasite ile (optimum seviye) çalıştıkları düşünülmektedir. Ancak ilgili alan yazınında bu düşüncenin net bir şekilde gerçekliği ortaya koymadığı görülmektedir. Hukuk ve Politika Merkezi (The Center for Law and Social Policy) tarafından yapılan açıklamada, örgütte gerçekleşen verimlilik kayıplarının, 
işgörenlerin devamsızlık yaptıkları günlerle (\%28) karşılaştırıldığında, presenteeism davranışlarının gerçekleştirildiği günlere (\%72) oranla çok daha fazla gerçekleştiği ve toplamda 250 milyar doları bulan yıllık verimlilik kayıplarının yaklaşık 180 milyar dolarının presenteeism davranışlarından kaynaklandığı ifade edilmektedir (Middaugh, 2007:172).

Özmen (2011, s.9) ve Çoban (2015, s.17) tarafından presenteeism davranışlarına örnek gösterilebilecek bazı eylemler şunlardır:

- Online alışveriş yapmak,

- TV izlemek,

- Bilgisayar oyunu oynamak,

- Kişisel randevular almak,

- Internet aracılığıyla aile bireyleri veya arkadaşlarla haberleşmek,

- Kişisel ödemeler yapmak,

- İş dişında internette zaman geçirmektir.

Hem ruhsal hem de fiziksel açıdan rahatsızlıkları olmalarına rağmen işgörenlerin çalışma konusunda zorlanmaları presenteeismi tetikleyici faktörlerin en başında yer almaktadır. Özellikle işgörenlerin performans baz alınarak değerlendirilmesi ve ücret sistemlerinin performanslar üzerine kurulu olması da presenteeismi meydana getiren başlıca faktörler olarak ele alınmaktadır. Örgüt kültürü, örgüt içi belirsizlik, yönetici ve yönetim tarzları, işgören özerkliğinin olmaması ve düşük ücretler de yine presenteeism olgusu ile ilişkilendirilmektedir (Middaugh, 2007, s.103105).

Özmen (2011, s.9) tarafından presenteeismin nedenlerine yönelik gerçekleştirilen çalışma sonuçları şu şekildedir:

- İşgörenin aşırı iş yükünün olması ve son şanslarını kullandığı düşüncesi $(\% 31,6)$,

- İşgörenin hissettiği suçluluk duygusu ve profesyonellik algısı $(\% 27,7)$,

- İşgörenin keyifsiz olma halini dikkate almama (\%15,1),

- İssgörenin işe gelmediği durumlarda görevine yönelik değişikliklerden endişe duyması $(\% 13,4)$,

- İşgörenin yaşaması olası negatif tepkilerden çekinmesi $(\% 9,4)$,

- İşgörenin işyerinde olması ve işte var olmanın muhtemel sonuçlarlyla bizzat ilgilenme isteğidir $(\% 2,8)$. 
İlgili alan yazın incelendiğinde presenteeism olgusuyla yakından ilişkili olan absenteeism (devamsızlık), verimlilik, tükenmişlik, stres, işten ayrılma niyeti ve iş/yaşam dengesi gibi konular ile ilgili çalışmaların varlığı tespit edilmekle birlikte işgören performansı ile ilişkilendirilen çalışmalara rastlanılmamıştır. Bu bilgiler doğrultusunda, presenteeismin işgören performansı ile ilişki ve etkileri bu çalışmada ele alınmıştır.

Psikolojik ve fiziksel açıdan problemler yaşayan işgörenler, sadece iş yaşamlarında değil aynı zamanda iş dışı yaşamlarında da ortaya konulan eylemlerde tam olarak başarıya ulaşamayacaklardır. İşgörenlerin içerisinde yer aldığı sorunlar insani ilişkilerini, hedeflerini ve çalışmalarını engelleyen öncüller olarak sürekli karşılarına çıkacaktır. Bu yönde engellere sahip işgörenlerin ise kendilerini tam anlamıla işlerine odaklanabilmesi beklenen bir durum değildir. Bu odaklanma problemi ise işgörende performans ve verimlilik düşüklüklerine neden olacaktır.

\section{İşgören Performansı}

Kurulan bütün örgütlerin temel amacı yüksek düzeyde performans sergileyerek sürdürülebilir rekabetçi avantaj elde etmek, uzun dönemde gelişimlerini ve yaşamlarını devam ettirmektir. Bazı örgütler performans kriteri olarak pazar payını, karlılığ 1 ya da kaliteyi kabul etmektedir. Bazıları ise performans kriteri olarak maliyetleri, müşteri odaklı olmayı ve verimliliği kabul etmektedir. İşte bu sebepten dolayı her işletme penceresinden performansın anlamı ve içeriği farklılık sergilemektedir. Bununla birlikte günümüzün sürekli değişkenlik gösteren endüstriyel koşullarında performans olgusunun içeriğinin ve boyutlarının yeniden şekillendirilmesi ve tanımlanması zorunlu görülmektedir (Erkut vd., 2001, s.11).

İşörenlerin görevlerini hangi seviyede yerine getirdikleri veya iş yapabilme kapasite/yeteneklerinin ne olduğunun tespiti örgütlerde karşılaşılan temel problemlerin başında gelmektedir. Bu temel problem ise performans olgusunun bu denli önem kazanmasına sebep olmuştur (Çalık, 2003, s.89).

Kökeni Fransizca "performance" terimine dayanan performans olgusunun sözlük anlamı "kapasitenin kullanım derecesidir". Örgütte işgörenlerin, örgütün hedeflerine yönelik olarak işe ilişkin neleri başarabildiğini nicelik ve nitelik olarak ifade eden olgu performans olarak 
tanımlanmaktadır. Bu noktada örgütler adına en önemli performans ölçütü işgörenlerin bireysel performanslarıdır. Çünkü işgören performansı ne kadar üst düzeyde olursa örgütün performansı da o kadar yukarıda olacaktır (Şehitoğlu ve Zehir, 2010, s.144).

Tüm bu bilgiler ışığında işgören performansı ise; yapılan işin bir parçası olarak işgörenlerin işe yönelik olarak sergiledikleri faaliyetlerle ilgilidir veya elde edecekleri ücret karşılığında ortaya konulması gerekli emek olarak nitelendirilmektedir (Bekiş vd., 2013, s.20).

İşörenlerin kendilerinden beklenen performansı ortaya koyabilmeleri için motivasyonlarının üst seviyede olması gerekmektedir. İşgören motivasyonunun üst seviyede gerçekleştirilebilmesi içinde örgüt tarafından işgörenlere gerekli fırsatların sunulması, terfi olanaklarının var olması, tatmin edici ücret politikasının izlenmesi ve iş arkadaşları tarafından gereken yakınlık, ilgi ve samimiyet ortamının geliştirilmesi gerekmektedir (Gupta, 1982, s.135-136).

İşgören performansı yalnız araştırmacılar adına değil aynı zamanda örgütler, yöneticiler ve çalışanlar için de önemli bir olgudur. Örgütler arzu ettikleri amaçlarına ulaşabilmek ve sürdürülebilir rekabetçi avantajı sağlayabilmek adına hiç şüphe yok ki gerçekleştirilecek faaliyetlerde üst düzey performans sergileyen işgörenlere ihtiyaç duymaktadır. Ortaya koyulan üst düzey performans aynı zamanda işgörenler içinde son derece önem arz etmektedir. İşinde yüksek başarı ortaya koymak ve görevini gereklerine uygun bir şekilde tamamlayabilmek işgörenler adına bir tatmin ve gurur kaynağı olarak görülebileceği gibi daha yüksek maddi kazanç, daha iyi bir kariyer ve sosyal itibar sağlamak adına da gereken bir ön koşul olarak görülmektedir (Sonnetag ve Freese, 2002, s.95).

İşgörenlerin yaptıkları işlerde yetkilerinin ve sorumluluklarının neler olup olmadığını bilmemesi durumunda yaşanan problemler, işe yönelik planlı ve net amaç ve standartların olmaması, işinde zamanını doğru şekilde planlayabilmeye yönelik şüphe duyulması, biçimsel rol davranışlarının ve iş tanımlarının net olarak tanımlanamaması gibi problemler işgörenlerin rol çatışması ve rol belirsizliği yaşamalarına sebebiyet vermektedir. Böylesi bir durum ise, işgörenin performansına negatif yönde yansımaktadır (Ceylan ve Ulutürk, 2006, s.49). 


\section{Araştırma Yöntemi}

Bu bölümde, araştırmanın amacı, önemi, kapsamı, sınırlılıkları, veri toplama aracı, ölçekleri, hipotezleri ve modelinden bahsedilmektedir.

\section{Araştırmanın Amacı, Önemi, Kapsamı ve Sınırlılılar}

$\mathrm{Bu}$ araştırmanın amac1; eğitim kurumlarında çalışan öğretmenlerin presenteeism algılarının performanslarına olan etkilerini analiz etmek ve bu eylemlerin bazı değişkenlere göre farklılık gösterip göstermediğini ortaya koymaktır. Presenteeism olgusu, çalışan bireylerin fiziksel ya da psikolojik olarak hasta olmalarına rağmen işlerine fiilen devam etmesi ve düşük verimde çalışması olarak değerlendirilmekte ve örgütler adına ciddi bir maliyet unsuru oluşturmaktadır. Bu durum çoğu sektörde olduğu gibi eğitim sektöründe de etkisini yoğun ve net bir şekilde göstermektedir. Eğitim kurumlarında insani ilişkilerin yoğunluğundan, hizmet alanlarının özel durumlarından ve işin tabiatından kaynaklanan stres düzeyi yoğun iş ortamı, yorucu ve uzun çalışma saatleri ve çalı̧̧ma düzenleri presenteeismin artmasına neden olan unsurlar olarak ortaya çıkmaktadır. Aynı zamanda son dönemlerde örgütler arası rekabetin şiddetinin artmasına paralel olarak performans olgusu da önemini bir hayli arttırmıştır. Performans olgusunun bu denli önem kazanmasının temel nedeni, örgütlerin sürdürülebilir başarıyı gerçekleştirebilmek adına hem bireysel hem de örgütün genel performansının arttırılması gerekliliğidir. Bu noktada ilk olarak işgörenlerin performanslarının arttıılması gerekmektedir. Örgütün performansı da dolaylı bir şekilde işgören performansının artmasıyla artış gösterecektir. Hem yabancı hem de yerli alan yazınında presenteeismle ilgili çok fazla araştırmanın mevcut olmamasından dolayı bu araştırmanın alan yazına ciddi katkısının olacağı düşünülmektedir.

Araştırma evrenini, Akdeniz Bölgesinde yer alan Kahramanmaraş ve Mersin illerinde görev yapan eğitim kurumu çalışanları (öğretmenler) oluşturmaktadır. Araştırmanın evreni ne denli büyürse o kadar ulaşılması zorlaşmakta ve soyutlaşmaktadır. Araştırma kapsamına dahil edilen evrenin geniş bir alanı kapsaması, evrenin tamamına ulaşabilmek ko- 
nusunda enerji, maliyet ve zaman problemlerini beraberinde getireceğinden dolayı, belirlenen evren dahilinde örneklem seçilmiştir (Karasar, 2005, s.110-127). Araştırma kapsamında örneklem sayısı tespit edilirken, olasılıklı örnekleme yöntemlerinden olan tabakalı örnekleme yönteminden faydalanılmış ve her bir şehirden/tabakadan alınacak örneklem sayısı için şu formül kullanılmıştır (Ural ve Kılıç, 2013:38).

Kahramanmaraş ve Mersin illerinin her biri için;

$$
n=\frac{\mathrm{N} \cdot z^{2} \cdot \sigma^{2}}{(\mathrm{~N}-1) \cdot H^{2}+z^{2} \cdot \sigma^{2}}
$$

$\mathrm{Bu}$ formülde; $\mathrm{H}$ (örneklem hatası) değeri 0,$10 ; \mathrm{z}(a=0,05$ anlamlılık düzeyinin karşılığı olan teorik değer) değeri 1,96; $\sigma$ (standart sapma) değeri 0,5 olarak ele alınmıştır. Milli Eğitim Bakanlığının 2017 Milli Eğitim İstatistikleri yayını verilerine göre; Kahramanmaraş' ta 1430 okulda 15118 ve Mersin'de 1341 okulda 21820 öğretmenin görev yaptığ belirlenmiştir. Bu doğrultuda, Kahramanmaraş'ta 266; Mersin'de 268 olmak üzere toplam 534 öğretmene ulaşılması gerektiği belirlenmiştir. Araştırma kapsamında Kahramanmaraş ve Mersin illerindeki okullarda 910 öğretmene anket uygulanmış ve bu anketlerin 829 tanesi değerlendirme dâhil edilmiştir.

Tablo 1. Değerlendirmeye Alınan Öğretmenlerin İllere Göre Dă̆ılımları

\begin{tabular}{lll}
\hline Şehir & Okul Sayısı & Öğretmen Sayısı \\
\hline Kahramanmaraş & 12 & 362 \\
\hline Mersin & 18 & 467 \\
\hline Toplam & 30 & 829 \\
\hline
\end{tabular}

$\mathrm{Bu}$ araştırma, araştırmanın yürütüldüğü dönemdeki (Haziran 2018Kasım 2018) iki ilde yer alan eğitim kurumlarında ve bu kurumlarda görev yapan kişilerin görüşleriyle, anket formunda yararlanılan ölçekten elde edilen verilerle sınırlıdır. Araştırma evrenini oluşturan çalışanların sayılarının fazla olması dolayısıyla gözlem, mülakat, deney ve anket gibi veri toplama yöntemlerinden yalnızca anket yöntemi kullanılmıştır. 


\section{Veri Toplama Aracı ve Kullanılan Ölçekler}

Araştırmada 829 kişiye anket uygulaması yapılmış olup, bu anketler birebir görüşmeler vasıtasıyla toplanmıştır. Anketler eğitim kurumlarında öğretmenlere uygulanmıştır. Araştırmada uygulanan ankette katılımclarla ilgili demografik sorulara ( 9 adet), presenteeism boyutlarını (6 ifade) ve işgören performansını (4 ifade) ölçen ifadelere yer verilmiştir. Presenteeismi ölçmek adına, Koopman vd. (2002) tarafından geliştirilen ve yine Koopman vd. (2008) tarafından revize edilen ölçek kullanılmıştır. İlgili ölçek, sonraki yıllarda yapılan birçok çalışmada; Coşkun 2012; Despiegel vd. 2012; Wan vd. 2014; Zhang vd. 2015; Kigozi, vd. 2017; Uribe vd. 2017 geçerliliği ve güvenilirliği onaylanarak kullanılmıştır. Bu ölçekte, presenteeism iki alt boyut olarak ele alınmıştır. Bu boyutlar; işi tamamlama ve dikkat dağınıklığından kaçınmadır. Ölçek toplam 6 ifade (işi tamamlamayla ilgili 3, dikkat dağınıklığından kaçınma ile ilgili 3 ifade) içermektedir. Ölçeğin orijinal faktörlerine sadık kalınarak yapılan bu araştırmada işi tamamlama alt boyutu ters kodlanmıştır. İşgören performansını ölçmek adına Kirkman ve Rosen (1999), daha sonrada Sigler ve Pearson (2000) tarafından geliştirilen araştırmada da kullanılan, Çöl (2008)'den alınan işgören performans ölçeği kullanılmıştır. Anket tek boyut ve 4 ifadeden meydana gelmektedir. Ölçeklerde beşli Likert derecelemesi (1- Kesinlikle katılmiyorum 5- Kesinlikle katılıyorum) kullanılmıştır. Toplanan verileri analiz edebilmek adına SPSS 23.0 programından yararlanılmıştır. Bu programla katılımcı bireylerin sosyo-demografik özelliklerini belirleyebilmek adına frekans analizinden, presenteeism ve performans arasındaki ilişki için korelasyon ve etki için regresyon analizinden ve değişkenlerin sosyo-demografik özelliklere göre farklılaşmasını tespit edebilmek adına da Kruskal Wallis ve Mann Whitney $\mathrm{U}$ testi analizlerinden faydalanılmıştır.

\section{Araştırma Modeli ve Hipotezler}

Örgütlerde presenteeism davranışlarının işgören performansını negatif yönde etkileyeceği düşünülmektedir. Bu araştırmanın ana amac1; öğretmenlerin presenteeism algılarının performansları üzerindeki etkilerini 
tespit etmektir. $\mathrm{Bu}$ araştırmanın ana amacı doğrultusunda oluşturulan araştırmanın temel hipotezleri şunlardır:

- H1: Presenteeism ile işgören performansı arasında negatif yönde ilişki vardir.

- $\quad$ H$_{2}$ : İşi tamamlama (presenteeism boyutu) işgören performansını negatif yönde etkilemektedir.

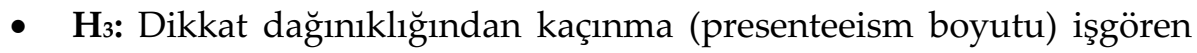
performansını negatif yönde etkilemektedir.

- Ha: Presenteeism (işte var olamama) alt boyutları üzerinde sosyo-demografik özellikler anlamsal bir farklılığa sebep olmamaktadır.

- H5: İşgören performansı üzerinde sosyo-demografik özellikler anlamsal bir farklılığa sebep olmamaktadır.

$\mathrm{Bu}$ hipotezler doğrultusunda, Şekil 1'de yer alan araştırma modeli çizilmiş olup, yapılan analizlerle hipotezler test edilmiştir.

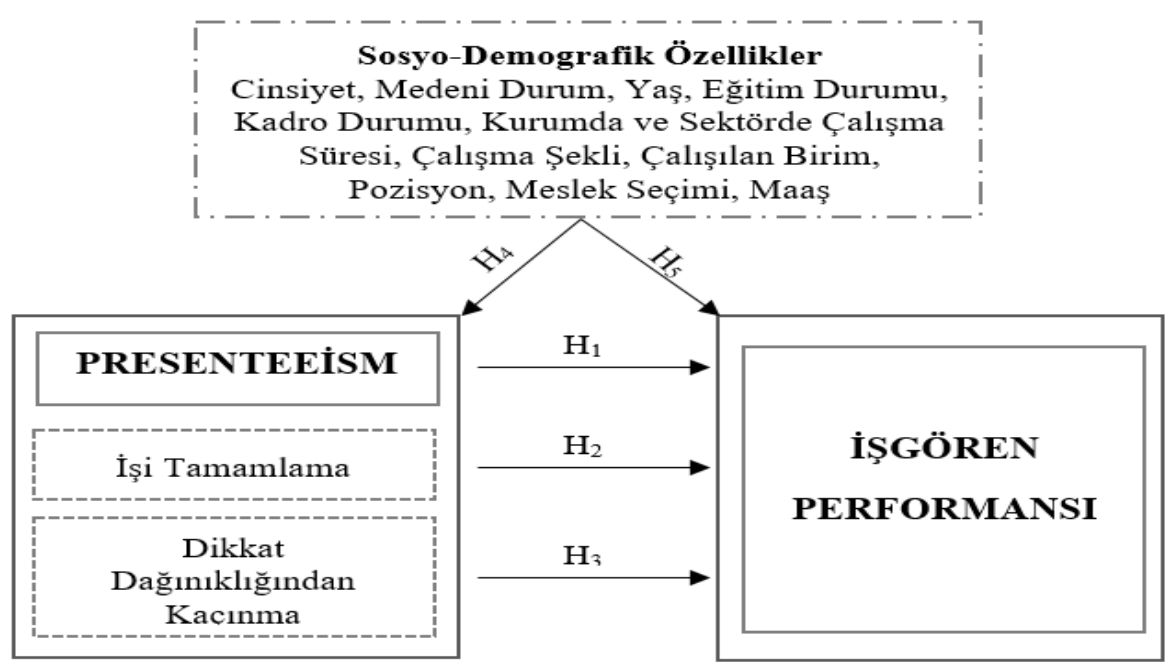

Şekil 1. Araştırma Modeli

\section{Araştırma Bulguları}

Bu bölümde, anketler sonucu elde edilen veriler analiz edilerek değerlendirilmektedir. 


\section{Sosyo-Demografik Özelliklere İlişkin Bulgular}

Tablo 2. Katılımcıların Sosyo-Demografik Özelliklerine İlişkin Frekans Analizi Bulgularn

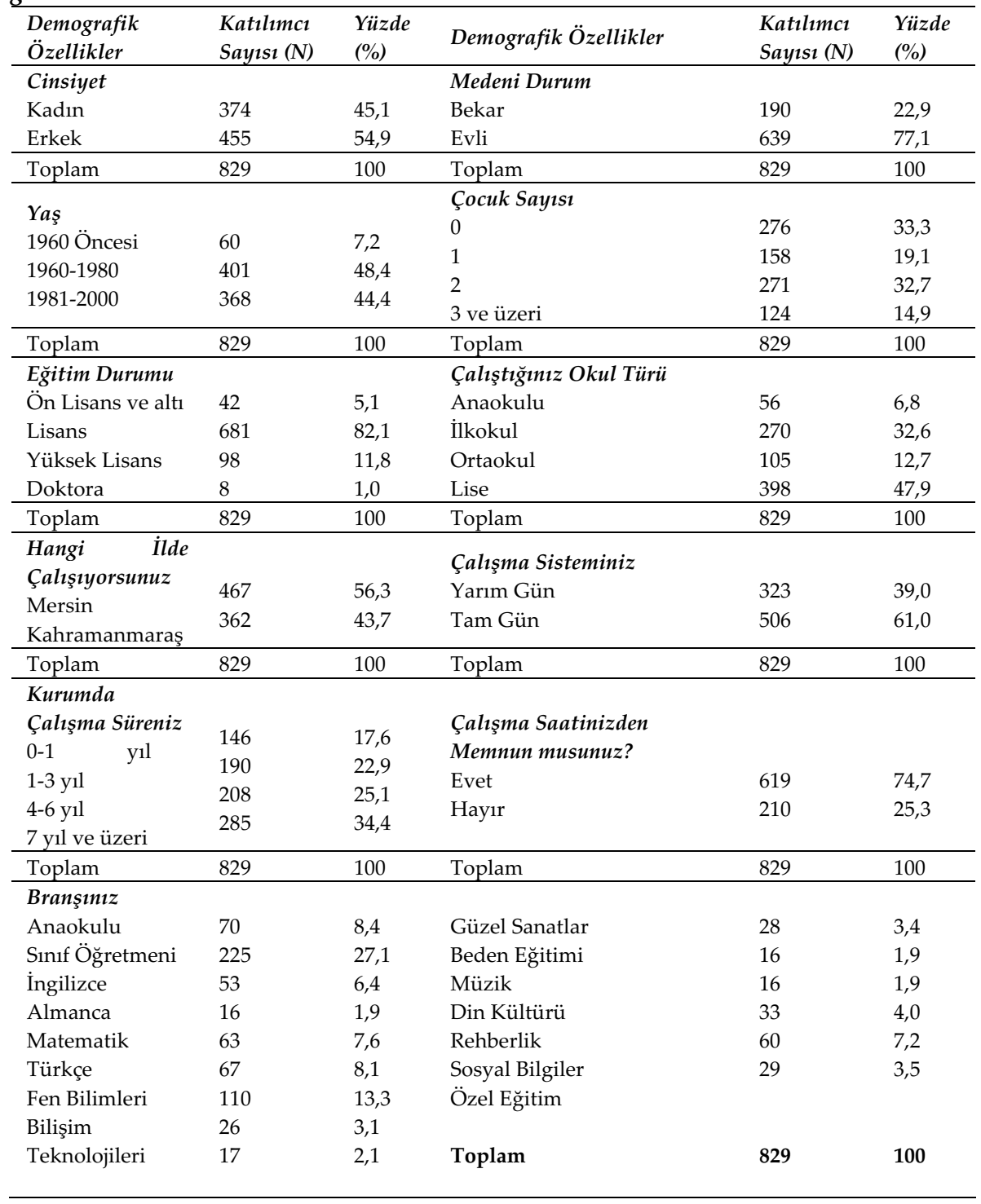


Katılımc1 bireylerin sosyo-demografik özelliklerini belirleyebilmek amaciyla yapilan frekans analizi sonucunda elde edilen bulgular Tablo 2 ' de yer almaktadır.

Tablo 2'de araştırma kapsamındaki eğitim kurumlarında çalışan öğretmenlerin sosyo-demografik özelliklerine yönelik yüzde ve frekans dağılımları mevcuttur. Bu dağılımlara göre, araştırmaya katılan öğretmenlerin; \%45,1'i kadın, \%54,9'u erkek olarak belirlenmiştir. Araştırmaya katılan öğretmenlerin \%7,2'si 1960 yılı ve öncesi, \%48,4'ü 1960-1980 yılları arasında ve \%44,4'ü 1980-2000 yılları arasında doğmuştur. Bu bireylerin \%22,9'u bekâr ve \%77,1'i evlidir. Eğitim durumları incelendiğinde; katılımc bireylerin \%82,1'i lisans, \%11,8'i yüksek lisans düzeyinde eğitim seviyesine sahiptir. Araştırmaya katılan öğretmenlerin \%56,3'ü Mersin ilinde, \%43,7'si ise Kahramanmaraş ilinde görev yapmaktadır. Söz konusu öğretmenlerin çalıştıkları okul türü incelendiğinde; \%6,8'i anaokulu, $\% 32,6$ 's ilkokul, \%12,7'si ortaokul ve \%47,9'u ise lisede çalışmaktadır. Aynı zamanda bu bireylerin \%39,0'u yarım gün, \%61,0'i ise tam gün çalışmaktadır. Çalışma saatinden memnuniyet durumları incelendiğinde ise; katılımcı bireylerin $\% 74,7^{\prime}$ si çalışma saatlerinden memnuniyet duyarken, \%25,3'ü ise çalışma saatlerinden memnuniyet duymamaktadır. Araştırmaya katılan öğretmenlerin branşları incelendiğinde; katılımcı bireylerin \%8,4'ü anaokulu, \%27,1'i sınıf, \%6,4'ü İngilizce, \%7,6's1 matematik, \%8,1'i Türkçe, \%13,3'ü fen bilimleri (Fizik, Kimya, Biyoloji), \%4,0'ü rehberlik, \%7,2' si sosyal bilgiler ve \%3,5'i özel eğitim branşı öğretmenidir.

\section{Güvenilirlik Analizleri}

Tablo 3. Araştırmada Yer Alan Ölçeklere İlişkin Güvenilirlik Analizi Sonuçları

\begin{tabular}{lll}
\hline Kullanılan Ölçekler & $\begin{array}{l}\text { Ifade Sayısı } \\
\text { (N of Items) }\end{array}$ & $\begin{array}{l}\text { Cronbach's } \\
\text { Alpha } \\
\text { Katsayıları }(\boldsymbol{\alpha})\end{array}$ \\
\hline İşi Tamamlama (Presenteeism Boyutu) & 3 & 0,817 \\
\hline Dikkat Dağınıklığından Kaçınma (Presenteeism Boyutu) & 3 & 0,829 \\
\hline İşören Performansı & 4 & 0,829 \\
\hline
\end{tabular}


Araştırmada presenteeism ile alt boyutları ve işgören performansını ölçebilmek için kullanılan ölçeklere yönelik gerçekleştirilen güvenilirlik analizi bulguları Tablo 3'de yer almaktadır. Güvenirlilik analizinde, Cronbach's Alfa Katsayısı (a) güvenilirlik göstergesi olarak kullanılmıştır (Güriş ve Astar, 2014, s.245).

Tablo 3'e incelendiğinde; presenteeism alt boyutlarının ve işgören performansının Cronbach's Alfa Katsayılarının (a) 0,70 üzerinde değerlere sahip oldukları görülmektedir. Alan yazını incelendiğinde sosyal bilimler alanında alfa değeri 0,70 veya üzerinde bir değere sahipse araştırma ölçeği güvenilir olarak ifade edilmektedir (Nunally, 1978; Akt: Gürbüz ve Şahin, 2014, s.305). Tablo 3' de görüldüğü üzere araştırmada kullanılan ölçeklerin tamamı kabul edilen alfa (a) sınırı olan 0,70 değerinin üzerinde bir değere sahiptir. Bu ise araştırma kapsamına dâhil edilen değişkenlerin güvenilir bir şekilde ölçümlendiğini ifade etmektedir.

\section{Hipotez Testlerine İlişkin Bulgular}

Hipotezleri test etmeden önce, verilerin normal dağılım gösterip göstermediğini tespit edebilmek adına Kolmogorov-Smirnov testi analizi yapılmıştır. Test sonuçlarına göre; her bir boyutun anlamlılık düzeyinin 0,05'ten küçük olduğu tespit edilmiş ve sosyo-demografik özellikleri test edebilmek adına veri setine non-parametrik testlerden Mann Whitney U testi ve Kruskal Wallis testi analizleri uygulanmıştır. Bununla birlikte araştırma modelinde yer alan değişkenler arasındaki ilişkilerin düzeyinin ve yönünün belirlenmesine yönelik gerçekleştirilen korelasyon analizi ve bağımsız değişkenlerin bağımlı değişkenler üzerindeki etkisinin tespitine ilişkin de regresyon analizi bulgularına yer verilmektedir.

Tablo 4. Ankette Kullanılan Ölçeklere Yönelik Korelasyon Analizi

\begin{tabular}{|c|c|c|c|c|}
\hline & 1 & 2 & 3 & 4 \\
\hline Presenteeism (1) & 1,000 & & & \\
\hline İşi Tamamlama (2) & $\begin{array}{l}512^{* *} \\
000\end{array}$ & 1,000 & & \\
\hline Dikkat Dağınıklığından Kaçınma (3) & $\begin{array}{l}509^{* *} \\
, 000\end{array}$ & $\begin{array}{l}-, 479 \\
627\end{array}$ & 1,000 & \\
\hline İşgören Performansı (4) & $\begin{array}{l}-153^{* *} \\
, 000\end{array}$ & $\begin{array}{l}-174 \\
, 000\end{array}$ & $\begin{array}{l}-, 040^{* *} \\
, 718\end{array}$ & 1,000 \\
\hline
\end{tabular}

${ }^{*} r=$ korelasyon katsayısı; $p<0,05$ düzeyinde anlamlı 
Tablo 4'de ankette kullanılan ölçeklerin alt boyutlarının aralarındaki ilişkilerin yönünü ve düzeyini ölçmek için yapılan korelasyon analizi sonuçları yer almaktadır. Yapılan korelasyon analizi sonuçlarına göre; presenteeism ile işgören performansı arasında negatif yönde çok zayıf düzeyde anlamlı $(0,00<\mathrm{r}<0,25 ; \mathrm{p}<0,05)$ ilişki tespit edilmiştir. Elde edilen veriler neticesinde; "presenteeism ile işgören performansı arasında negatif yönde ilişki vardır" ifadesi ile test edilmeye çalışılan $\mathbf{H 1}$ hipotezi kabul edilmiştir. Alan yazını incelendiğinde presenteeism ile performans arasındaki ilişki ve etkinin analizine yönelik bir çalışmaya rastlanılmamıştır. Ancak performans kavramı ile yakından ilişkilendirilen verimlilik kavramıyla ilgili az da olsa çalışma mevcuttur. Elde edilen sonuçlar bu çalışmalarla (Braakman-Jansen vd. 2012; Yavan 2017) paralellik göstermektedir.

Presenteeism alt boyutlarının işgören performansı üzerindeki etkisini tespit etmek adına yapılan regresyon analizine ilişkin bulgulara ise Tablo 5 ve Tablo 6'da yer verilmektedir

Tablo 5. İşi Tamamlama (Presenteeism Boyutu) ile İşgören Performansı Arasındaki Ilisskiye Ait Korelasyon Matrisi ve Regresyon Analizi

\begin{tabular}{|c|c|}
\hline \multicolumn{2}{|l|}{ BAĞIMLI DEĞISSKEN } \\
\hline BAĞIMSIZ DEĞİŞKEN & İşgören Performanst \\
\hline $\mathbf{R}^{2}$ & 0,028 \\
\hline $\mathbf{F}$ & $\begin{array}{l}24,050 \\
(\mathrm{p}=0,000)\end{array}$ \\
\hline İşi Tamamlama & $\begin{array}{l}{ }^{*} \mathbf{r}-0,174 \\
\text { B 4,483 } \\
\text { p 0,000 }\end{array}$ \\
\hline
\end{tabular}

${ }^{*} r$ (korelasyon katsayısı)

Yapılan korelasyon analizi sonuçlarına göre; işi tamamlama (presenteeism boyutu) ile işgören performansı arasında negatif yönde çok zayıf düzeyde anlamlı bir ilişki vardır $(0,00<r<0,25 ; \mathrm{p}<0,01)$. Yapılan regresyon analizi sonuçlarına göre, işgören performansındaki değişkenliğin $\% 2,8^{\prime}$ inin $\left(R^{2}=0,028\right)$ bağımsız değişken işi tamamlama tarafından açıklanabildiği görülmektedir. Elde edilen sonuçlara göre, işgören performansı istatistiksel olarak anlamlı düzeyde işi tamamlamadan etkilenmektedir $(F=24,050 ; p<0,05)$. " $B$ " değerine (regresyon katsayısına) göre; işi tamamlamadaki bir birimlik artışın, işgören performansı üzerinde 4,483 
birimlik bir azalış sağladığ tespit edilmiştir $(\mathrm{p}<0,05)$. Bu sonuçlar $\mathbf{H}_{2}$ hipotezini yeterli kanıtla desteklemektedir. Değişkenlere ve alt boyutlarına yönelik olarak gerçekleştirilen korelasyon analizi tablosunda da bahsedildiği gibi presenteeism ile performans arasındaki ilişki ve etkinin analizine yönelik bir çalışmaya rastlanılmamıştır. Presenteeism ile performans kavramı arasındaki ilişkiyi inceleyen çalışmalar incelendiğinde elde edilen sonuçlar bu çalışmalarla (Collins vd., 2005; Braakman-Jansen vd. 2012; Yavan 2017) paralellik göstermektedir.

Tablo 6. Dikkat Dağınıklı̆̆ından Kaçınma (Presenteeism Boyutu) ile İşgören Performansı Arasındaki İlişkiye Ait Korelasyon Matrisi ve Regresyon Analizi

\begin{tabular}{|c|c|}
\hline \multicolumn{2}{|l|}{ BAĞIMLI DEĞISŞKEN } \\
\hline BAĞIMSIZ DEĞĠisKEN & İşgören Performanst \\
\hline $\mathbf{R}^{2}$ & 0,000 \\
\hline F & $\begin{array}{l}0,130 \\
(p=0,718)\end{array}$ \\
\hline Dikkat & ${ }^{*} \mathbf{r}-0,040$ \\
\hline Dağınıklığından & B 4,184 \\
\hline Kaçınma & p 0,000 \\
\hline
\end{tabular}

${ }^{*} r$ (korelasyon katsayısi)

Yapılan korelasyon analizi sonuçlarına göre; dikkat dağınıklığından kaçınma ile işgören performansı arasında anlamlı bir ilişki bulunamamıştır $(0,00<r<0,25 ; p>0,01)$. Yapılan regresyon analizi sonuçlarına göre, işgören performansındaki değişkenliğin bağımsız değişken dikkat dağınıklığından kaçınma tarafından açıklanmadığı $\left(R^{2}=0,000\right)$ görülmektedir ( $\mathrm{R}^{2 \prime}$ nin 0 'a yaklaşması ya da 0 düzeyinde değer alması modelin veriye uygun sağlanmadığını veya bağımlı değişkendeki değişmenin, bağımsız değişken ya da değişkenler tarafından açılanmadığını göstermektedir). Elde edilen sonuçlara göre, işgören performansı istatistiksel olarak anlamsız düzeyde dikkat dağınıklığından kaçınmadan (presenteeism boyutu) etkilenmektedir ( $F=0,130 ; p>0,05)$. " $B$ ” değerine (regresyon katsayısına) göre; dikkat dağınıklığından kaçınmadaki (presenteeism boyutu) bir birimlik artışın, işgören performansı üzerinde 4,184 birimlik bir azalma sağladığı tespit edilmiştir $(\mathrm{p}<0,05)$. Bu sonuçlar $\mathbf{H}_{3}$ hipotezini yeterli kanıtla desteklememektedir.

İşgören performansı ile presenteeismin "işi tamamlama" alt boyutu arasındaki ilişki incelendiğinde negatif yönde çok zayıf düzeyde anlamlı 
ilişkilerin varlığı tespit edilmiştir. Sorumluluk sahibi olan işgörenler özellikle yaptıkları işleri yarım bırakmama ve yarım kalan işleri tamamlama noktasında son derece hassas davranmaktadırlar. Fakat buradaki presenteeism davranışı ve sorumlu kişilik özellikleri arasında oldukça ince bir çizgi bulunmaktadır. Sorumlu kişilik özelliğine sahip olan işgörenler hasta olmalarını çok fazla önemsemeyerek, iş amaçlarını gerçekleştirmeye odaklanmakta ve işlerini eksiksiz bir şekilde tamamlayabilmek adına kendilerini enerjik hissetmektedirler. Aksine presenteeism davranışı sergileyen işgörenler ise biçimsel rol davranışları ya da zorunluluklardan dolayı işe gelmektedirler. Bu işgörenlerdeki amaç; işi bir şekilde tamamlamak suretiyle, zaman kaybetmemek ve yöneticinin gözüne girebilmektir. $\mathrm{Bu}$ şekilde davranan işgörenler kısa vadede verimli birer çalışan olarak görülseler dahi örgütler adına uzun vadede faydadan çok zarara sebebiyet vermekte ve örgütsel verimliliği düşürmektedirler.

Tablo 7. Sosyo-Demografik Özelliklere İlişkin Mann Whitney U Testi Analizi

\begin{tabular}{|c|c|c|c|c|c|c|c|}
\hline $\begin{array}{l}\text { Dem. } \\
\text { Özellik }\end{array}$ & & Değişken & $N$ & $\begin{array}{l}\text { Sira } \\
\text { Ort. }\end{array}$ & $u$ & $Z$ & $P$ \\
\hline \multirow{6}{*}{ Cinsiyet } & $\dot{I}_{s ̧ i} i$ & Erkek & 455 & 422,04 & 88,286 & 0,939 & 0,348 \\
\hline & Tamamlama & Kadın & 374 & 406,44 & & & \\
\hline & Dikkat Dă̆. & Erkek & 455 & 410,33 & 82,961 & $-0,623$ & 0,534 \\
\hline & Kaçınma & Kadın & 374 & 420,68 & & & \\
\hline & İşgören & Erkek & 455 & 413,02 & 84,185 & $-0,266$ & 0,790 \\
\hline & Performansi & Kadın & 374 & 417,41 & & & \\
\hline \multirow{6}{*}{$\begin{array}{l}\text { Medeni } \\
\text { Durum }\end{array}$} & $\dot{I}_{s ̧ i}$ & Bekâr & 190 & 393,14 & 64,859 & 1,443 & 0,149 \\
\hline & Tamamlama & Evli & 639 & 421,50 & & & \\
\hline & Dikkat & Bekâr & 190 & 410,49 & 61,561 & 0,297 & 0,766 \\
\hline & Dağ. Kaçınma & Evli & 639 & 416,34 & & & \\
\hline & İşg̈ren & Bekâr & 190 & 385,57 & 66,277 & 1,952 & 0,051 \\
\hline & Performansi & Evli & 639 & 423,72 & & & \\
\hline \multirow{6}{*}{$\begin{array}{l}\text { Görev } \\
\text { Yapılan } \\
\text { İl }\end{array}$} & $\dot{I}_{s ̧ i}$ & Mersin & 467 & 403,49 & 89,901 & 1,582 & 0,114 \\
\hline & Tamamlama & K.Maraş & 362 & 429,85 & & & \\
\hline & Dikkat & Mersin & 467 & 416,32 & 83,910 & $-0,181$ & 0,856 \\
\hline & Dağ. Kaçınma & K.Maraş & 362 & 413,30 & & & \\
\hline & İşören & Mersin & 467 & 407,07 & 88,232 & 1,100 & 0,271 \\
\hline & Performansi & K.Maraş & 362 & 425,23 & & & \\
\hline \multirow{6}{*}{$\begin{array}{l}\text { Çalışma } \\
\text { Sistemi } \\
\text { (Tam Gün/ } \\
\text { Yarım } \\
\text { Gün) }\end{array}$} & $\dot{I}$ Isi & Tam Gün & 506 & 413,93 & 81,178 & $-0,162$ & 0,871 \\
\hline & Tamamlama & Yarım & 323 & 416,67 & & & \\
\hline & Dikkat Dă̆. & Tam Gün & 506 & 401,95 & 75,116 & $-1,975$ & 0,048 \\
\hline & Kaçınma & Yarım & 323 & 435,44 & & & \\
\hline & İşören & Tam Gün & 506 & 416,82 & 82,642 & 0,279 & 0,780 \\
\hline & Performanst & Yarım & 323 & 412,14 & & & \\
\hline
\end{tabular}


Sosyo-demografik özellikleri test edebilmek için veri setine non-parametrik testler olan Kruskal Wallis Testi ve Mann Whitney U Testi analizleri uygulanmıştır.

Yapılan Mann-Whitney U analizi testleri neticesinde sosyo-demografik özelliklerin (cinsiyet, medeni durum, görev yapılan il ve çalışma sistemi) presenteeism alt boyutları ve işgören performansı üzerinde anlamsal bir farklılığa sebep olmadığı tespit edilmiştir.

Tablo 8. Sosyo-Demografik Özelliklere İlişkin Kruskal Wallis Testi Analizi

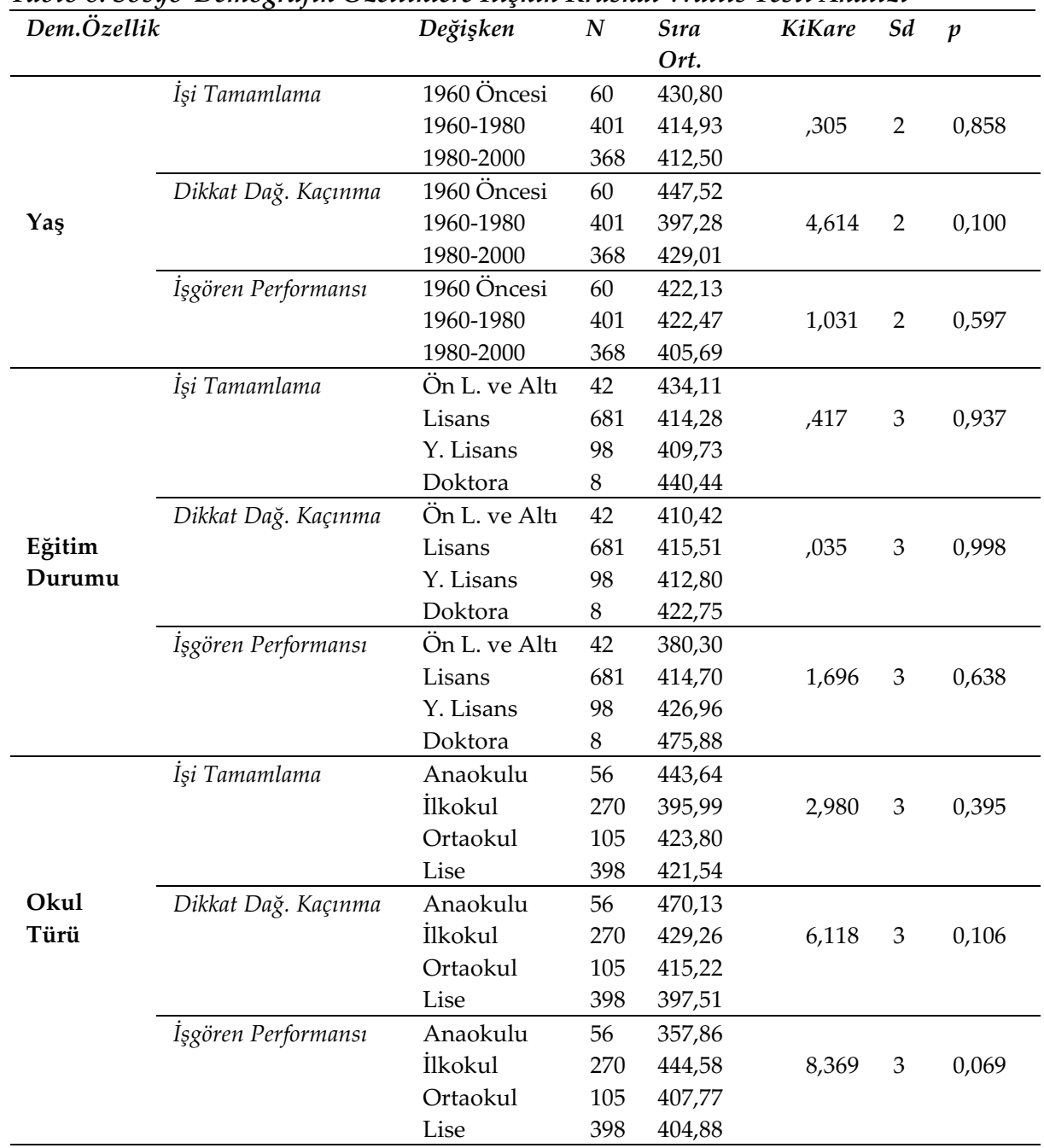




\begin{tabular}{|c|c|c|c|c|c|c|c|}
\hline & İşi Tamamlama & $0-1$ yıl & 146 & 414,22 & \multirow{4}{*}{5,046} & \multirow{4}{*}{3} & \multirow{4}{*}{0,168} \\
\hline & & $1-3$ yil & 190 & 391,11 & & & \\
\hline & & $4-6$ y1l & 210 & 443,52 & & & \\
\hline & & 7 yıl üzeri & 283 & 410,28 & & & \\
\hline \multirow{8}{*}{$\begin{array}{l}\text { Kurumda } \\
\text { Çalışma } \\
\text { Süresi }\end{array}$} & Dikkat & $0-1$ yıl & 146 & 408,71 & & & \\
\hline & Dağınıklı̆̆ından & $1-3$ yil & 190 & 402,72 & 1,063 & 3 & 0,786 \\
\hline & Kaçınma & $4-6$ y1l & 210 & 418,14 & & & \\
\hline & & 7 yıl üzeri & 283 & 424,16 & & & \\
\hline & İsgörren & $0-1$ yıl & 146 & 381,60 & & & \\
\hline & Performansl & $1-3$ yil & 190 & 408,85 & 5,650 & 3 & 0,130 \\
\hline & & $4-6$ yıl & 210 & 441,09 & & & \\
\hline & & 7 yil üzeri & 283 & 417,00 & & & \\
\hline
\end{tabular}

Yapılan Kruskal Wallis analizi testleri neticesinde sosyo-demografik özelliklerin (yaş, eğitim durumu, okul türü, kurumda çalışma süresi ve branş) presenteeism alt boyutları ve işgören performansı üzerinde anlamsal bir farklılığa sebep olmadığ 1 tespit edilmiştir. Bu sonuçlar $\mathbf{H}_{3} \mathbf{v e} \mathbf{H}_{4}$ hipotezini yeterli kanitla desteklemektedir. İlgili alan yazını da incelendiğinde sosyo-demografik özelliklerin (cinsiyet, medeni durum, görev yapılan il, çalışma sistemi, yaş, eğitim durumu, okul türü ve branş) presenteeism alt boyutları ve işgören performansı üzerinde anlamlı bir farklılığa sebep olmadığı tespit edilmiştir. Elde edilen sonuçlar alan yazını ile (Altın ve Demirtaş 2018; Çiftçi vd., 2018; Türkay ve Yalçın Kayıkçı 2017; Zengin ve Kaygın 2016; Oruç 2015; Baysal vd., 2014; Beğenirbaş ve Turgut 2014; Bıyık ve Aydoğan 2014; Anık ve Baysal 2012, Beğenirbaş ve Meydan 2012; Goodwin vd., 2011; Balcı 2016;) paralellik göstermektedir.

\section{Sonuç}

Hem yerel hem de uluslararası temelde ekonominin işletmeler üzerindeki etkileri, müşteri ve tüketicilerin istek, beklenti ve davranışlarında meydana gelen ani değişimler ve küreselleşmenin etkilerini bariz bir şekilde göstermesi, işletmeler arasındaki rekabetin şiddetinin artmasına yol açmıştır. Artık çağımızın endüstriyel toplumlarında finansal yapı, makine-teçhizat, teknolojik imkanlar, fırsatlar ve yenilikler açısından birbirine son derece yakınlaşmakta olan işletmeler sürdürülebilir rekabetçi avantajı sağlama adına insan kaynağını en önemli unsur olarak görmektedir. İnsan kaynaklarının bu denli stratejik bir unsur olarak ele 
alınmasındaki en temel husus ise arzu edilen başarıların sağlanması, örgütsel verimlilik, etkinlik ve performansın sadece fiziksel ve ruhsal açıdan sağlıklı işgörenler tarafından gerçekleştirilebilecek olmasından kaynaklanmaktadır.

İşgörenlerin hastalanmalarına, ruhsal ve fiziksel anlamda rahatsızlıkları olmalarına rağmen işte olmaları ve düşük verimlilik seviyelerinde çalışmaları şeklinde tanımlanan presenteeism kavramı tam bu noktada ortaya çıkmakla beraber örgütte performans, verimlilik ve sağlığa ilişkin yeni bir kavram olarak örgütlerin önemle dikkate almaları gereken konuların birisi haline gelmiştir.

Sosyo-psikolojik bir varlık olan bireylerin iş çevrelerinde, örgüt, yönetim ve iç ve diş müşterilere yönelik yükledikleri anlam ve değer, işgörenlerin performanslarıyla direkt olarak ilişkilidir. Entelektüel, fiziksel ve duygusal emeğin bir arada yönetilmesi gereken sektörlerin en başında eğitim sektörü gelmektedir. İnsan kaynağı günümüz iş dünyasında örgütsel rekabetin sağlanmasında en önemli rolü üstlenmekte ve insan unsuru temelli ortaya çıkan sorunlar, örgütler ve kamu kurumlarında var olduğu kadar eğitim ve öğretim veren okullar açısından da varlığını ve önemini korumaktadır.

Günümüzün artan rekabetçi endüstrilerinde performans olgusu örgütler adına son derece etkin bir unsur olarak ifade edilmektedir. Özellikle örgütler adına sürdürülebilir başarının elde edilmesinin hem örgütsel hem de bireysel performansın birlikte artması sayesinde gerçekleşebileceği kuşkusuz bilinmekle beraber bu durum performansın önemini ortaya koymaktadır. Bu başarının elde edilmesinin ise ilk şartı işgören performansının arttırılmasıdır. Çünkü örgütsel performansın artışı doğrudan işgörenin bireysel performansının artışına bağlıdır. Bu noktada ise bireysel performansı etkileyen unsurların en başında ise presenteeism olgusu gelmektedir.

$\mathrm{Bu}$ araştırmada presenteeismin işgören performansı üzerindeki etkileri ve sosyo-demografik özellikler açısından incelenmesi amaçlanmış olup, bu doğrultuda 2 ilde yer alan eğitim kurumlarında görev yapan 829 öğretmene anket uygulanmıştır. Presenteeism ve işgören performansını ölçmek adına geçerliliği ve güvenilirliği onaylanmış toplam 10 ifadeden oluşan iki ölçek kullanılmıştır. Ayrıca anket formunda katılımcıların sosyo-demografik özelliklerini ortaya koymaya yönelik 9 soru yöneltilmiştir. Verilerin 
normal dağılım gösterip göstermediği tespit edilmiş olup, elde edilen tüm veriler SPSS programı aracılı̆̆ıla analiz edilmiş ve şu sonuçlara ulaşılmıştır:

- Yapılan frekans analizi sonuçlarına göre; katılımcıların çoğunluğu erkektir. Yine araştırmaya katılan bireylerin çoğunluğu evli ve 60 yaş ve altındadır. Katılımcıların büyük çoğunluğu lisans düzeyinde eğitime sahiptir. Bilindiği üzere artık, öğretmen olabilmek için en az lisans düzeyinde eğitime sahip olmak gerekmektedir. Daha önceki yıllarda, meslek lisesi ve önlisans düzeyinde üniversiteden mezun olanlar öğretmen unvanını alabiliyordu. Katılımcıların arasında önlisans ve altı düzeyinde mezunların olmasının bundan kaynaklandığı düşünülmektedir. Aynı zamanda araştırmaya katılan bireylerin büyük çoğunluğunun anaokulu, sınıf, matematik, Türkçe ve fen bilimleri öğretmeni oldukları, ilkokul ve lise düzeyi okullarda çalıştıkları ve çalışma saatlerinden oldukça memnun oldukları tespit edilmiştir.

- Yapılan korelasyon analizi sonuçlarına göre; presenteeism ve işi tamamlama (presenteeism boyutu) ile işgören performansı arasında negatif yönde çok zayıf düzeyde anlamlı ilişki tespit edilmiştir. Dikkat dağınıklığından kaçınma (presenteeism boyutu) ile işgören performansı arasında anlamlı bir ilişki bulunamamıştır. Elde edilen veriler neticesinde; "presenteeism ile işgören performansı arasında olumsuz yönde ilişki vardır" ifadesi ile test edilmeye çalışılan $\mathbf{H}_{\mathbf{1}}$ hipotezi kabul edilmiştir.

- Yapılan regresyon analizi sonuçlarına göre; işi tamamlama (presenteeism boyutu) işgören performansını negatif yönde etkilemektedir. İşgören performansındaki değişkenliğin \%2,8'inin işi tamamlama tarafından açıklandığı görülmekle birlikte, işi tamamlamadaki bir birimlik artışın, işgören performansı üzerinde 4,483 birimlik bir azalış meydana getirdiği tespit edilmiştir. Aynı zamanda dikkat dağınıklığından kaçınma (presenteeism boyutu) ile presenteeism arasında anlamlı bir ilişki bulunamamakla birlikte işgören performansındaki değişkenliğin dikkat dağınıklığı tarafından açılanmadığı $\left(R^{2}=0,000\right)$ tespit edilmiştir. Elde edilen veriler neticesinde; "işi tamamlama işgören performansı olumsuz yönde etkilemektedir" ifadesi ile test edilmeye çalışı- 
lan $\mathbf{H}_{2}$ hipotezi kabul, "dikkat dağınıklığından kaçınma işgören performansını olumsuz yönde etkilemektedir" ifadesi ile test edilmeye çalışılan $\mathbf{H}_{3}$ hipotezi red edilmiştir.

- Yapılan Mann Whitney U testi ve Kruskal Wallis testi analizi sonuçlarına göre; sosyo-demografik özelliklerin (cinsiyet, medeni durum, görev yapılan il, çalışma sistemi, yaş, eğitim durumu, okul türü ve branş) presenteeismin alt boyutları (işi tamamlama ve dikkat dağınıklığından kaçınma) ve işgören performansı üzerinde anlamlı bir farklılığa sebep olmadığ senteeism alt boyutları üzerinde sosyo-demografik özellikler anlamsal bir farklılığa sebep olmamaktadır" ifadesiyle test edilmeye çalışılan $\mathbf{H}_{4}$ hipotezi ve "işgören performansı üzerinde sosyo-demografik özellikler anlamsal bir farklılığa sebep olmamaktadır" ifadesiyle test edilmeye çalışılan $\mathbf{H}_{5}$ hipotezi kabul edilmiştir.

Gerçekleştirilen araştırma neticesinde elde edilen ilişki sonuçları nispeten düşük çıksa da farklı sektör (kamu-özel), il ve evren/örneklem üzerinde gerçekleştirilecek araştırmalarda bu ilişki sonuçları yükselebilir. Sonuç olarak bu araştırma ile elde edilen sonuçlardan ve literatürdeki bilgilerden yola çıkılarak aşağıdaki öneriler getirilebilir:

Presenteeisme ilişkin uygulayıcı ve araştırmacılara aşă̆ıdaki öneriler sunulabilir:

- Birincil adım, ilgili konulara yönelik olarak yöneticilerin farkındalığ1nın sağlanması yoluyla, işyeri sağlığının geliştirilerek sağlıklı bir çalışma ortamının düzenlenmesi gerekmektedir.

- İşgörenlerin presenteeism davranışları sergilemelerinin önüne geçmek amacıyla; tedavisi mümkün olan sağlık problemleri için işgörenlerin özlük haklarının zarara uğramadığı, maddi kayıp yaşanmadığ ve cezai yükümlülüklerin uygulanmadığı bunun aksine işyerine ve işe yönelik gerçekleştirilen korumacı eylemlerden dolayı takdir edildiği hastalık izinleri uygulamalarının yürürlüğe konması gerekmektedir.

- Örgütler arzuladığı başarılara ulaşabilmek için istihdam politikalarını belirlerken örgüt ve birey sağlığını ele almak zorundadır. Bu sebeple politikalar şekillendirilirken yedekli istihdam politikaları (succession planning) yürürlüğe konmalı ve çeşitli sebepler dolayısıyla işe gele- 
meyen, performansı, etkinliği ve verimliliği azalan çalışanların açıklarını kapatmak suretiyle yeniden üst seviyelere çıkarabilmek için yeterli personel istihdamı sağlanmış olmalıdır.

- Örgüt içerisinde işgörenlere atfedilen görevlere yönelik net ve tam iş tanımları yapılarak işgörenlerin rol belirsizliği ve rol çatışması yaşamalarının önüne geçilmelidir. Çünkü bireylerin ifa ettikleri işe yönelik sahip olduğu özellikler, sorumluluklar ve görevler belirsiz bir nitelik gösterirse rol çatışması ve rol belirsizliği yaşanmakta ve dolaylı yollardan hem işgören verimliliği ve performansı hem de örgütsel verimlilik ve performans azalmaktadır.

- İşgörenler sadece örgütsel güvenin sağlandığı ve örgüt kültürünün oturduğu örgütlerde yüksek performans ortaya koyabilmektedirler. Örgütlerde bu sebepten dolayı güven ortamı oluşturulmalı, işgörenlerin işe gelmedikleri zamanlarda endişeye kapılmaması sağlanıp, daha da sağlıklı bir şekilde örgüte dönmelerinin önü açılmalıdır.

- Örgütlerde stres, hem çalışan hem de yöneticilerin davranışlarını negatif yönde etkilemekte, çalışanların düşük performans ortaya koymalarına ve mutsuz olmalarına, örgütlerin ise etkinlikten ve verimlilikten uzaklaşmalarına neden olmaktadır. Bu yüzden örgütler, presenteeism davranışlarını artıran, işgören performansını da azaltan değişkenlerin elimine edilmesine yönelik olarak harekete geçilebilmesi için stres faktörlerine üzerinde durmalıdır.

- Örgütler adına iş/yaşam dengesinin kurulması, işgörenlerin kendilerini daha iyi hissetmeleri için kullanılabilecek çok önemli bir yönetimsel stratejik insan kaynağı aracıdır. İş/yaşam dengesini sağlamak adına sıkıntı yaşayan işgörenlerin performans, etkinlik, verimlilik ve motivasyonları düşmekte ve dolayısıyla da hem bireysel hem de örgütsel açıdan kayıplar yaşanmaktadır.

- İşgören performansına ilişkin ilişkin uygulayıcı ve araştırmacılara aşă̆ıdaki öneriler sunulabilir:

- Performans değerlendirme sistemi kendi içerisinde sürekli olarak geribildirim mekanizması ile çalışmalı yani sistem her daim kendisini güncelleyerek test etmeli ve hatalardan arındırılmalıdır.

- Geribildirim mekanizması sadece sistemin kendi içinde değil aynı zamanda işgörenlere de yönelik olmalıdır. Dönütler somut ve net bir şekilde işgörenlerle paylaşılarak, bireylerin eksik gördükleri noktalarda 
kendilerini geliştirmelerine zemin hazırlanmalı, özeleştiri imkanı sağlanmalıdir.

- Yönetim kademeleri, işgörenlerin performanslarına etki eden unsurların neler olduğunun farkında olmalı ve bu performansları iyileştirici adımlar atmalıdır. Aynı zamanda öğretmenlerin performanslarının doğru bir şekilde değerlendirilmesi için öğretimsel liderlik ve hizmetkar liderliğin karşılaştırılması suretiyle adım atılması faydalı olacaktir.

- Performans değerlendirme sonuçlarının insan kaynakları planlamasinda kullanılması, atama, tayin, terfi, ceza ve ödül gibi kritik kararlarda önemli rol oynaması işgörenler adına performans değerlendirmenin önemini ve sisteme yönelik inancı da arttırmaktadır.

- Değerlendirilen kıstaslar gözden geçirilerek nesnel ve nicel bir şekil almalı, öğretmenlerin branşları ve okul kademeleri temelinde yeniden düzenlemeye tabi tutulmalıdır.

- Yönetimler tarafından değerlendirme süreçleri psikolojik bir baskı unsuru olarak asla ele alınmamalı, otorite sağlamaya ilişkin tutum ve davranışlardan uzak kalınmalı, öğretmenlerle beraber karşılıklı güven ve saygı temelinde bir ilişki kurulmalıdır. Bunun yanı sıra okul yönetimleri performans değerlendirme süreçlerini öğretmenlerin motivasyon düzeylerini ve örgütsel vatandaşlık davranışlarını artırıcı ve iş tatmini sağlayıcı bir faktör olarak ele almalıdır.

İlerde gerçekleştirilecek olan araştırmalarda; araştırma değişkenlerinin farklı bölge ve illerde, farklı sektörlerde ve farklı çaplardaki işletmelerde değişik sonuçlar verip vermeyeceği test edilebilir. Bununla birlikte araştırma modeline farklı değişkenlerin eklenmesi ve farklı meslek grupları açısından da değerlendirilmesi suretiyle araştırmanın kapsamı genişletilebilir. Bu yönde adımların atılmasının ise; araştırma bulgularının ve sonuçlarının genellemesinin yapılabilmesi adına fayda sağlayabileceği düşünülmektedir. 


\title{
EXTENDED ABSTRACT
}

\section{The Effects of Presenteeism Perceptions of Educational Institution Employees on Their Performance and It's Analysis With Regardds to the Socio-Demographic Characteristics}

\author{
Hüseyin Çiçeklioğlu - Mustafa Taşliyan \\ Mersin University, Sütçü Imam University
}

Presenteeism (not being on the job actively) is defined as being at work not fully functioning because of reduced performance although they are sick and having mental or physical problems. Although the term of Presenteeism is a phenomenon just introduced regarding to the performance, productivity, and health at work, it is one of the main issues, which should be discussed carefully by related organizations. The aim of this study is to analyze the effect of presenteeism perception of teachers working in educational intuitions on their performance and to reveal whether these actions differ according to some variables. In addition to this, it is aimed to establish the level and the direction of the relations between the variants of the study. In accordance with this purpose, a questionnaire has been carried out on 829 teachers working in the educational intuitions in Mersin and Kahramanmaraş located in Mediterranean Region of Turkey.

The questionnaire forms have been carried out on the teachers working in educational intuitions. In the forms, socio-demographic questions (9) about participant individuals and the statements evaluating the dimensions (6 statements) of presenteeism (not being on the job actively) and employee performance (4 statements) have been introduced. To evaluate the presenteeism perception of the participants, presenteeism scale (Stanford Presenteeism Scale) has been used, which was developed by Koopman et al. (2002) and revised by them in 2008. Reliability and validation of the scale has been approved and used in many studies made in later years by Kigozi, et al. 2017; Uribe et al. 2017; Zhang et al. 2015; Wan et al. 2014; Despiegel et al. 2012; Coşkun 2012. In the scale, the phenome- 
non of presenteeism is discussed with two lower-dimensions. These dimensions are "completing work" and "avoiding distraction." The scale includes 6 statements ( 3 statements for completing work and 3 statements for avoiding distraction). The lower dimension of completing work is coded reversely in the study made basing on presenteeism scale original factors. To measure employee performance, employee performance scale has been used, which was used in the study developed firstly by Kirkman and Rosen (1999), and then Sigler and Pearson (2000) and quoted by Çöl (20089. The related scale consists of one dimension and 4 statements. In the scales used in the study, 5 likert scale (1- Strongly agree 5- Strongly disagree) has been used. To analyze collected data, it is benefited from SPSS 23.9 programme. With this programme, frequency test is used to determine socio demographic characteristics of participants, correlation analysis to determine the relation between presenteeism and performance, regression test for impact, Kruskal Wallis test, and Mann Whitney $\mathrm{U}$ test analysis to determine the differentiation of related variants according to socio-demographic characteristics.

Presenteeism behaviors are considered to decrease employee performance in organizations. The general aim of this study is to determine the effect of presenteeism perception of teachers on their performance. Main hypothesizes of this study which are introduced in line with the general aim of this study are as below;

- H1: There is a negative relationship between presenteeism and employee performance

- H2: Completing work affects employee performance negatively

- H3: Avoiding distraction affects employee performance negatively

- H4: Socio-demographic characteristics cause a meaningful difference on presenteeism lower dimensions.

- H5: Socio-demographic characteristics cause a meaningful difference on employee performance.

According to the results of frequency analysis, the majority of the participants are male. Similarly, the majority of the participants are married and under the age of 60. Most of the participants have a license degree. As it is already known, it requires at least a license degree to be a teacher. In previous years, those graduated from vocational high school or those hav- 
ing an associate degree could be a teacher. It is why there are some individuals among participants having associate degree or beneath. At the same time it is determined that most of the participants are teachers of preschool, primary school, math, Turkish language and physical sciences and working in primary or high schools and they are happy with their working hours.

According to the correlation analysis results, a weak meaningful relationship has been found between presenteeism (not being on the job actively) and completing work (a lower dimension of presenteeism) in a negative way. There has not been found any meaningful relationship between avoiding distraction (a lower dimension of presenteeism) and employee performance. As a result of the data required, $\mathrm{H} 1$ hypothesis, which tried to be tested with the statement that "There is a negative relationship between presenteeism and employee performance" is accepted.

According to the regression analysis results, completing work (a lower dimension of presenteeism) affects employee performance negatively. It is seen that $2,8 \%$ correlation of employee performance is explained by completing work and it is also established that 1 rate of increase in completing work has caused 4,483 rate of decrease in employee performance. At the same time, it is established that there is no meaningful relationship between avoiding distraction (a lower dimension of presenteeism) and presenteeism and correlation in employee performance cannot be explained by avoiding distraction $\left(R^{2}=0,000\right)$. As a result of the data required, $\mathrm{H} 2$ hypothesis, which tried to be tested with the statement that "Completing work affects employee performance negatively" is accepted but H3 hypothesis, which tried to be tested with the statement that "Avoiding distraction affects employee performance negatively" is denied.

According to Mann Whitney U test and Kruskal Wallis test analysis results, it has been established that socio-demographic characteristics (gender, marital status, city of duty, working system, age, education level, type of academe and field) do not cause a meaningful difference on the presenteeism lower dimensions (completing work and avoiding distraction) and employee performance. As a result of the data required, Hypothesis 4 stating, "Socio-demographic characteristics cause a meaningful difference on 
presenteeism lower dimensions" and Hypothesis 5 stating, "Socio-demographic characteristics cause a meaningful difference on employee performance" have been accepted.

\section{Kaynakça / References}

Anık-Baysal, İ., Baysal, G., Aksu, G. ve Aksu, N. (2014). Presenteeism (işte varolmama sorunu) ile örgütsel bağllık arasındaki ilişki: Adnan Menderes üniversitesi akademik personeli üzerinde bir uygulama, Electronic Journal Of Vocational Colleges, Özel Sayı, 134-152.

Aydın-Tükeltürk, Ş., Şahin, D. ve Yılmaz, İ.A. (2014). Turizm işletmelerinde presenteeism: İşte var olamama): Turizm işletmelerinde çalş̧an ilişkileri yönetimi içinde (s.281- 302.)Ankara: Detay Yayıncllık,

Balcı, O. (2016). İlköğretim okullarında görev yapan öğretmenler ve yöneticilerin örgütsel sinizm, kendini işe verememe (presenteeism) ve sosyal kaytarma arasındaki ilişkinin incelenmesi: Arnavutköy ilçesi örneği. Doktora Tezi, İstanbul Arel Üniversitesi, Sosyal Bilimler Enstitüsü,İstanbul.

Baysal, İ.A., Baysal, G., Aksu, G. ve Aksu, N. (2014). Presenteeism (işte varolmama sorunu) ile örgütsel bağllılık arasındaki ilişki: Adnan Menderes Üniversitesi akademik personeli üzerinde bir uygulama, Electronic Journal of Vocational Colleges, BÜROKON Özel Sayı, 134-152.

Beğenirbaş, M. ve Meydan, C.H. (2012). Duygusal emeğin örgütsel vatandaşlık davranışıyla ilişkisi: Öğretmenler üzerinde bir araştırma, Gazi Üniversitesi İ̈BF Dergisi, 14 (3), 159-181.

Beğenirbaş, M. ve Turgut, E. (2014). İş performansının sağlanmasında çalışanın duygusal emeğinin ve örgütte güven algısının etkileri, $\dot{I}_{\text {ş, }}$ Güç, Endüstri İlişkileri ve İnsan Kaynakları Dergisi, 16 (3), 131-149.

Bekiş, T., Bayram, A. ve Şeker, M. (2013). Kurumsal itibarın işgören performansı üzerindeki etkisinin belirlenmesine yönelik bir araştırma. Uluslararası Alanya İşletme Fakültesi Dergisi, 5 (2), 19-27.

Bıyık, Y. ve Aydoğan, E. (2014). Duygusal emek ile örgütsel vatandaşlık davranışı ilişkisi: Bir araştırma, Gazi Üniversitesi İ̈BF Dergisi, 16 (3), 159180.

Braakman-Jansen, Lma., Taal, E., Kuper I.H. ve Van De Laar, Mafj. (2012). Productivity loss due to absenteeism and presenteeism by different instruments in patients with ra and subjects without ra. Rheumatology (Oxford), 51, 354-61. 
Ceylan, A. ve Yıldırım H.U. (2006). Rol belirsizliği, rol çatışması, iş tatmini ve performans arasındaki ilişkiler, Doğuş Üniversitesi Dergisi, 7 (1), 4858.

Collins, J.J., vd. (2005). The assessment of chronic health conditions on work performance, absence, and total economic impact for employers, Journal of Occupational and Environmental Medicine, 47 (6), 547-557.

Çoban, Ö. (2015). Örgütlerde presenteeism sorunu. (Ed D. Küçükaltan, Ş. Aydın Tükeltürk ve G. Ç. Gürkan), Örgütsel davranışta güncel konular, (1. Bsm), Ankara: Detay Yayıncilı.

Coşkun, Ö. (2012). İki işyerinde işe devamsızlık ve kendini işe verememede etkili faktörlerin değerlendirilmesi. Yayınlanmamış Doktora Tezi, Ankara Üniversitesi Sağlık Bilimleri Enstitüsü, Ankara.

Çalık, T., (2003). Performans yönetimi: Tanımlar kavramlar ilkeler, Ankara, Gündüz Eğitim ve Yayıncllık.

Çiftçi, D., Meriç, E. ve Meriç, A. (2018). Presenteeism (işte var olamama) ve örgütsel özdeşleşme arasındaki ilişkinin incelenmesi. Sosyal Bilimler Dergisi, 1, 303-320.

Despiégel, N., Danchenko, N., François, C., Lensberg, B., ve Drummond, M. F. (2012). The use and performance of productivity scales to evaluate presenteeism in mood disorders. Value in Health, 15(8), 1148-1161.

Erkut, H. (2001). Değişimi başarıya dönüştürme MESDEM, İstanbul:MESS Yayınları.

Gupta, O.P. (1982). Commitment to work of industrial workers. New Delhi:Concept Publishing Company,.

Günbeyi, M. ve Gündoğdu, T. (2010). Polis teşkilatının "işkolik" çalışanları. Doğuş Üniversitesi Dergisi, 11 (1), 56-63.

Gürbüz, S. ve Şahin, F. (2014). Sosyal bilimlerde araştırma yöntemleri felsefe-yönetim-analiz, Ankara:Seçkin Yayın.

Güriş, S. ve Astar, M. (2014). Bilimsel araştırmalarda SPSS ile istatistik, İstanbul:DER Yayınları.

Johns, G. (2010). Presenteeism in the workplace: a review and research agenda. Journal of Organizational Behavior, 31, 519-542.

Karasar, N. (2005). Bilimsel araştırma yöntemi (Kavramlar-ilkeler-teknikler), Ankara:Nobel Yayın Dağıtım.

Kım, J. vd. (2016). Sickness experiences of Korean registered nurses at work: A qualitative study on presenteeism, Asian Nursing Research, 10, 3238. 
Kigozi, J., Jowett, S., Lewis, M., Barton, P.M., ve Coast, J. (2017). The estimation and inclusion of presenteeism costs in applied economic evaluation: a systematic review. Value in health: The journal of the International Society for Pharmacoeconomics and Outcomes Research, 20(3), 496-506.

Koopman, C. vd. (2002). Stanford presenteeism scale: health status and employee productivity, Journal of Occupational and Environmental Medicine, 44 (1), 1-12.

Middaugh, D.J. (2007). Presenteeism: sick and tired at work, Dermatology Nursing, 19 (2), 172-185.

Nunally, J.C. (1978). Psychometric theory, New York:McGraw-Hill.

Oruç, Ş. (2015). Presenteizm ile örgütsel sessizlik arasındaki ilişki üzerine bir araştırma. Yüksek Lisans Tezi, Aksaray Üniversitesi Sosyal Bilimler Enstitüsü, Aksaray.

Özmen, G. (2011). Presenteizm ile örgütsel bağlllık ilişkisi: tekstil çalışanları üzerine bir araştırma. Yüksek Lisans Tezi, Osmangazi Üniversitesi Sosyal Bilimler Enstitüsü, Eskişehir.

Saarvala, E. (2006). Presenteeism: The lastest attack on economic and human productivity. 6 Eylül 2018 tarihinde http://www.supportingadvancement.com/employment/general/saarvala presenteeism.pdf adresinden erişildi.

Sonnentag, S. ve Frese, M. (2002). Performance concepts and performance theory. Psychological Management of Individual Performance, 4-25.

Şehitoğlu Y. ve Zehir, C. (2010). Türk kamu kuruluşlarında çalışan performansının, çalışan sessizliği ve örgütsel vatandaşlık davranışı bağlaminda incelenmesi. Amme İdaresi Dergisi, 43 (4), 87-110.

Türkay, O. ve Yalçın-Kayıkçı, M. (2017). İşletmelerde duygu gösterim kuralları ve örgütsel vatandaşlığın duygusal emek üzerine etkileri, Ekonomik ve Sosyal Araştırmalar Dergisi, 13(2), 53-73.

Ural, A. ve Kılıç, İ. (2013). Bilimsel araştırma süreci ve spss ile veri analizi. Ankara:Detay Yayıncilik.

Uribe, J.M., Pinto, D.M., Vecino-Ortiz, A.I., Gómez-Restrepo, C., ve Rondón, M. (2017). Presenteeism, absenteeism, and lost work productivity among depressive patients from five cities of colombia. Value in health regional issues, 14, 15-19. 
Wan, H. C., Downey, L. A., ve Stough, C. (2014). Understanding non-work presenteeism: Relationships between emotional intelligence, boredom, procrastination and job stress. Personality and Individual Differences, 65, 86-90.

Yavan, Ö. (2017). Çalışanların işe gitmeme ve çalışıyor gibi görünme davranısları üzerine bir araştırma: Zonguldak Taşkömürü kurumu örneği, International Journal of Economic and Administrative Studies, 19, 249-276.

Zengin, Y. ve Kaygın, E. (2016). Tükenmişlik sendromu ile presenteeism (işte var ol(ama)ma arasındaki ilişkinin incelenmesi: Kars Sgk örneği, 15. Ulusal İşletmecilik Kongresi, İstanbul.

Zhang, W., Sun, H., Woodcock, S., Anis, A. (2015). Illness related wage and productivity losses: Valuing 'presenteeism'. Social Science \& Medicine, Elsevier, 147(3), 62-71.

\section{Kaynakça Bilgisi / Citation Information}

Çiçeklioğlu, H. ve Taşlıyan, M. (2019 Eğitim kurumu çalışanlarının presenteeism (işte var olamama) algılarının performanslarına olan etkisi ve sosyo-demografik özellikler açısından incelenmesi. OPUS-Uluslararası Toplum Araştırmaları Dergisi, 14(20), 22-53. DOI: 10.26466/opus.595134 